\title{
Effects of inhaled anesthetics sevoflurane and isoflurane on lung morphofunction and biological markers in experimental pulmonary and extrapulmonary acute respiratory distress syndrome
}

\author{
CS Samary ${ }^{1 *}$, MN Araujo ${ }^{1}$, CL Santos ${ }^{2}$, FF Cruz ${ }^{2}$, VM Cavalcanti ${ }^{2}$, LB Heil ${ }^{2}$, FC Fernandes ${ }^{2}$, NR Vilela ${ }^{2}$, PL Silva ${ }^{2}$, \\ PR Rocco ${ }^{2}$
}

From ESICM LIVES 2015

Berlin, Germany. 3-7 October 2015

\section{Introduction}

Experimental and clinical studies have shown that volatile anesthetics modulate the inflammatory process, which may be beneficial in the context of acute respiratory distress syndrome (ARDS). Furthermore, these agents may also protect type II epithelial cells minimizing the impairment on surfactant production. There are various triggers for ARDS, and differences in the initial insult combined with underlying conditions may result in the activation of different inflammatory mechanisms. Based on the aforementioned, we hypothesized that sevoflurane and isoflurane may act differently depending on the etiology of ARDS.

\section{Objectives}

To compare the effects of sevoflurane with isoflurane on lung mechanics and histology in experimental pulmonary (p) and extrapulmonary (exp) ARDS.

\section{Methods}

Twenty-four Wistar rats (300-350 g) were randomly allocated to receive Escherichia coli lipopolysaccharide intratracheally (200 $\mu \mathrm{g}, \mathrm{ARDSp})$ or intraperitoneally $(1,000$ $\mu \mathrm{g}$, ARDSexp). After $24 \mathrm{~h}$, animals were randomized into subgroups anesthetized with sevoflurane (1 MAC) or isoflurane (1 MAC). All animals were paralyzed and

${ }^{1}$ Federal University of Rio de Janeiro, Carlos Chagas Filho Biophysics Institute, Rio de Janeiro, Brazil

Full list of author information is available at the end of the article protective mechanically ventilated with $\mathrm{V}_{\mathrm{T}}=6 \mathrm{ml} / \mathrm{kg}$, $\mathrm{RR}$ $=80 \mathrm{bpm}, \mathrm{PEEP}=3 \mathrm{cmH}_{2} \mathrm{O}$, and $\mathrm{FiO}_{2}=0.4$ for $1 \mathrm{~h}$. Lung mechanics and arterial blood gases were analyzed at baseline and after $1 \mathrm{~h}$ anesthesia. At the end of the experiments, lungs were removed for histological and molecular biology analysis. A549 cells, alveolar type II epithelial cell line, were incubated with $E$. coli LPS, followed by treatment or not with sevoflurane and isoflurane.

\section{Results}

In ARDSp, sevoflurane reduced lung static elastance compared to baseline and was associated with lower alveolar collapse. Isoflurane resulted in no mechanical and morphological changes. In ARDSexp, both sevoflurane and isoflurane did not alter lung mechanics. Arterial blood gases did not differ between the different anesthetic agents and ARDS groups. Sevoflurane presented lower expression of interleukin (IL)-6 and pro-caspase 3 and higher surfactant protein (SP)-B expression compared to isoflurane in ARDSp. In ARDSexp, IL-6, pro-caspase 3 and SP-B expressions did not differ between sevoflurane and isoflurane. Additionally, sevoflurane increased the expression of SP-B in E. coli LPS-injured A549 cells.

\section{Conclusions}

Sevoflurane attenuates lung mechanics and atelectasis, probably through the stimulation of surfactant release in ARDSp, but no morphofunctional and biological 
parameters were affected in ARDSexp. Isoflurane presented no significant effects in both ARDS groups.

\section{Grant Acknowledgment}

FAPERJ, CNPq, CAPES, MS-DECIT

\section{Authors' details}

${ }^{1}$ Federal University of Rio de Janeiro, Carlos Chagas Filho Biophysics Institute, Rio de Janeiro, Brazil. ${ }^{2}$ Federal University of Rio de Janeiro, Rio de Janeiro, Brazil.

Published: 1 October 2015

\section{References}

1. Voigtsberger S, Lachmann RA, Leuter AC, Schlapfer M, Booy C, Reyes L, et al: Sevoflurane ameliorates gas exchange and attenuates lung damage in experimental lipopolysaccharide-induced lung injury. Anesthesiology 2009, 111(6):1238-1248.

2. Yue T, Roth Z'graggen B, Blumenthal S, Neff SB, Reyes L, Booy C, et al: Postconditioning with a volatile anaesthetic in alveolar epithelial cells in vitro. Eur Respir J 2008, 31(1):118-125.

doi:10.1186/2197-425X-3-S1-A571

Cite this article as: Samary et al:: Effects of inhaled anesthetics

sevoflurane and isoflurane on lung morphofunction and biological markers in experimental pulmonary and extrapulmonary acute respiratory distress syndrome. Intensive Care Medicine Experimental 2015 3(Suppl 1):A571.

\section{Submit your manuscript to a SpringerOpen ${ }^{\mathcal{D}}$ journal and benefit from:}

- Convenient online submission

- Rigorous peer review

- Immediate publication on acceptance

- Open access: articles freely available online

- High visibility within the field

- Retaining the copyright to your article 